Published in final edited form as:

Expert Rev Gastroenterol Hepatol. 2008 December ; 2(6): 803-816. doi:10.1586/17474124.2.6.803.

\title{
Advances in Anti-fibrotic Therapy
}

\author{
Zahra Ghiassi-Nejad and Scott L. Friedman, MD \\ Division of Liver Diseases, Mount Sinai School of Medicine
}

\section{Summary}

Sustained progress in defining the molecular pathophysiology of hepatic fibrosis has led to a comprehensive framework for developing anti-fibrotic therapies. Indeed, the single greatest limitation in bringing new drugs to the clinical setting is lack of clarity about clinical trial and treatment endpoints, not the lack of promising agents. A range of treatments, including those developed for other indications, as well as those specifically developed for hepatic fibrosis, are nearing or in clinical trials. Most are focused on attacking features of either hepatic injury and/or activated stellate cells and myofibroblasts, which are the primary sources of extracellular matrix, or scar proteins. Thus, features of injury and stellate cell activation provides a useful template for classifying these emerging agents, and point to a new class of therapies for patients with fibrosing liver disease.

\section{Keywords}

hepatic fibrosis; liver fibrosis; cirrhosis; hepatoprotection; stellate cells; myofibroblasts; cytokines; cytokine receptors; matrix degradation

\section{Introduction}

The rapid advances in understanding the pathophysiology of liver fibrosis have generated intense interest in exploiting these insights to develop anti-fibrotic therapies for patients with chronic liver diseases. While no agents are yet approved for this indication, there is a flurry of activity in both the academic and commercial sectors to develop effective anti-fibrotic drugs. However, a remaining obstacle is the need to establish effective endpoints of anti-fibrotic drugs that are not reliant on liver biopsy, since changes in extracellular matrix content are likely to evolve more slowly than molecular markers of fibrogenic activity. Thus, considerable effort is also being invested not only in new therapies, but also in defining novel markers of liver injury, fibrogenesis, and extracellular (ie., scar) content in the liver. These advances will further accelerate the progress already generated in developing anti-fibrotic therapies.

\section{Pathophysiology of Hepatic Fibrosis - A Framework for Therapies}

The now well-established pathways of hepatic fibrosis offer a useful template for defining points of therapeutic intervention ${ }^{1}$. Thus, a review of the cellular mechanisms of fibrosis are provided here, with emphasis on those pathways particularly amenable to therapeutic intervention.

Correspondence address: Scott L. Friedman MD, Box 1123, Mount Sinai School of Medicine, 1425 Madison Ave, Room 1170C, New York, NY 10029, Tel 212659 9501; Fax 212849 2574, scott.friedman@mssm.edu. 


\section{Initiating signals of injury}

Hepatic injury leads to initiation of fibrogenesis due to elaboration of key signals derived from hepatocytes, inflammatory cells and other non-parenchymal cells, in particular sinusoidal endothelial cells and Kupffer cells (liver macrophages). These fibrogenic stimuli include reactive oxygen species, hypoxia, inflammatory and immune responses, apoptosis and steatosis.

Oxidative stress-Oxidative stress through generation of reactive oxygen species (ROS) plays an important role in producing liver damage and initiating hepatic fibrogenesis. Oxidative disruption of lipids, proteins and DNA induces necrosis and apoptosis of hepatocytes, and amplifies the inflammatory response, resulting in the initiation of fibrosis. ROS also stimulate the production of profibrogenic mediators from Kupffer cells and both resident and circulatinginflammatory cells. These ROS are also directly fibrogenic and proliferative towards hepatic stellate cells $(\mathrm{HSCs})^{2}, 3$.

Hypoxia-Hypoxia has been recognized as a critical, early fibrogenic stimulus in which it up-regulates HIF-1 $\alpha$ expression by hepatic stellate cells (HSCs), which are a central regulator of fibrogensis (see below). This in turn induces vascular endothelial cell growth factor (VEGF) and its receptors, and stimulates type I collagen synthesis in HSCs 4, 5. Hypoxia also potentiates transforming growth factor- $\beta 1$ (TGF- $\beta 1$ ) expression, 6 contributing to both autocrine and paracrine loops that drive angiogenesis and fibrogenesis. Fibrosis and hypoxia amplify each other in the presence of persistent parenchymal injury, leading to a vicious cycle that disrupts normal tissue repair.

Inflammation and immune responses-Inflammation is an important element in the initiation and progression of hepatic fibrosis ${ }^{7}$. Inflammatory cells belonging to both innate immunity (e,g,. NK cells and macrophages) and adaptive immunity (e.g., T and B cells) are involved in the development of liver injury and fibrogenesis. They regulate pathogen elimination, cell killing (e.g., hepatocytes damage during anti-viral immune reaction), the regulation of inflammatory cells, recruiting and activating myofibroblasts, and spontaneous recovery of fibrosis ${ }^{8}, 9$.

Kupffer cells, the liver's tissue-specific macrophage population, are important effector cells in the hepatic inflammatory response. Nuclear factor kappa-B (NF-kB) activation in Kupffer cells drives expression of a number of inflammatory genes, including chemokines and other inflammatory mediators ${ }^{10-} 12$.

Apoptosis-Apoptosis or programmed cell death is a common feature of chronic liver disease, in particular apoptosis of hepatocytes. Apoptosis results in the generation of apoptotic bodies, which are then cleared by phagocytosis. While apoptosis was often thought to be noninflammatory, in fact it is a pro-inflammatory and fibrogenic stimulus. Kupffer cells secrete death ligands and tumor necrosis factor alpha (TNF-alpha) after engulfing apoptotic bodies

13. Similarly, the engulfment of apoptotic bodies by HSCs triggers a profibrogenic response with production of oxidative radicals, and up-regulation of both TGF- $\beta 1$ and collagen I expression 14, 15 .

Steatosis-Hepatic steatosis most commonly arises in liver diseases from insulin resistance and mitochondrial dysfunction. The steatosis in chronic hepatitis $\mathrm{C}$, alcoholic steatohepatitis (ASH) and non-alcoholic steatohepatitis (NASH) are all risk factors for fibrosis ${ }^{16,} 17$.

Even in simple steatosis there is evidence of stellate cell activation as assessed by expression of alpha smooth muscle actin in a study of patients with alcoholic fatty liver ${ }^{18}$. While steatosis 
may be not sufficient to perpetuate fibrosis by itself, it represents a "first hit" that renders hepatocytes susceptible to a "second hit" (e.g., oxidative stress, viral infection, or LPS), which propagates damage and provokes sustained fibrosis. A number of pathways may contribute to steatosis-related fibrogenesis in liver. These include: 1 ) enhanced oxidative stress; 2 ) increased susceptibility to apoptosis; 3) a dysregulated response to cellular injury; 4) Peroxisome proliferator-activated receptor (PPAR) signaling and activity; 5) dysregulation of leptin expression and signaling ${ }^{19}$.

\section{Cellular Sources of Fibrogenesis - Stellate cell activation and Myofibroblasts}

The identification of stellate cell activation as a key event in fibrogenesis has provided an important template for understanding the liver's response to injury (see Figure 1). Stellate cell 'activation' refers to the conversion of a resting vitamin A-rich cell to one that is proliferating, fibrogenic and contractile. While it is increasingly clear that other mesenchymal cell populations also contribute to extracellular matrix accumulation ${ }^{1}$, stellate cell activation remains the most dominant pathway leading to hepatic fibrosis. Activation consists of two major phases, Initiation and Perpetuation, followed by Resolution of fibrosis if injury subsides

- Initiation (also called a "pre-inflammatory stage"), refers to early changes in gene expression and phenotype that render the cells responsive to other cytokines and stimuli. Initiation results mostly from paracrine stimulation, including altered surrounding extracellular matrix, as well as exposure to lipid peroxide, LPS and products of damaged hepatocytes.

- Perpetuation results from the effects of these stimuli on maintaining the activated phenotype and generating fibrosis. Perpetuation involves autocrine as well as paracrine loops. It is comprised of several discrete responses including proliferation, contractility, fibrogenesis, matrix degradation, retinoid loss, and inflammatory cell infiltration.

- Resolution of fibrosis refers to pathways that either drive the stellate cell to apoptosis, senescence, or contribute to reversion of activated stellate cells to a more quiescent phenotype.

\section{Initiation}

Early events in liver injury that initiate stellate cell activation are outlined above. Paracrine stimulation is provided by all neighboring cell types, including: sinusoidal endothelium, Kupffer cells, hepatocytes, and platelets. Endothelial cells are also likely to participate in conversion of TGF $\beta$ from the latent to active, profibrogenic form. Platelets are another important source of paracrine stimuli, including PDGF, TGF $\beta 1$, and EGF.

As noted above, Kupffer cell infiltration and activation also contribute to stellate cell activation. Kupffer cells stimulate matrix synthesis, cell proliferation, and release of retinoids by stellate cells through the actions of cytokines (especially TGF 31 ) and reactive oxygen intermediates/ lipid peroxides ${ }^{20}$.

Hepatocytes are a potent source of fibrogenic lipid peroxides, as reviewed above. Hepatocyte apoptosis following injury also promotes stellate cell initiation through a process mediated by Fas 15,21 . This process may involve the tumor necrosis factor-related apoptosis-inducing ligand (TRAIL) 15,21 . Apoptotic fragments released from hepatocytes are also fibrogenic towards cultured stellate cells 13, and activate Kupffer cells 22. 


\section{Perpetuation}

Perpetuation of stellate cell activation involves at least seven discrete changes in cell behavior: proliferation, chemotaxis, fibrogenesis, contractility, matrix degradation, retinoid loss, and WBC chemoattractant / cytokine release. The net effect of these changes is to increase accumulation of extracellular matrix. Cytokine release by stellate cells can amplify the inflammatory and fibrogenic tissue responses, and matrix proteases may hasten the replacement of normal matrix with one typical of the wound "scar."

Proliferation-PDGF is the most potent stellate cell mitogen identified ${ }^{23}$. Induction of PDGF receptors early in stellate cell activation increases responsiveness to this potent mitogen ${ }^{24}$. Downstream pathways of PDGF signaling have been carefully characterized in stellate cells and include PI3 kinase and $\mathrm{Na}^{+} / \mathrm{H}^{+}$exchange ${ }^{25}, 26$. Other mitogenic stimuli in stellate cells include vascular endothelial cell growth factor ${ }^{27}$, thrombin and its receptor ${ }^{28,}{ }^{29}$, EGF, $\mathrm{TGF} \alpha$, keratinocyte growth factor ${ }^{30}$ and $\mathrm{bFGF}^{31}$.

Chemotaxis-Stellate cells can migrate towards cytokine chemoattractants leading to their accumulation in zones of injury. Potent stellate cell chemoattractants include PDGF ${ }^{32,} 33$, MCP- $1{ }^{34}$ and CXCR $3{ }^{35}$. In contrast, adenosine ${ }^{36}$ blunts chemotaxis and may immobilize cells once they reach the site of injury. The mechanical features of stellate cell chemotaxis have recently been explored, revealing that PDGF-stimulated chemotaxis is associated with cell spreading at the tip, movement of the cell body towards the stimulant, and retraction of trailing protrusions associated with transient myosin phosphorylation ${ }^{37}$.

Fibrogenesis-Stellate cells generate fibrosis not only by increased cell numbers, but also by increasing matrix production per cell. The best-studied component of hepatic scar is collagen type I, the expression of which is regulated both transcriptionally and post-transcriptionally in hepatic stellate cells by a growing number of stimuli and pathways.

The most potent stimulus for production collagen I and other matrix constituents by stellate cells is TGF $\beta 1$, which is derived from both paracrine and autocrine sources (see 38, 39 for reviews). Signals downstream of TGF $\beta 1$ include a family of bifunctional molecules known as Smads, upon which many extracellular and intracellular signals converge to fine-tune and enhance TGF $\beta$ 's effects during fibrogenesis 38 . TGF $\beta 1$ also stimulates the production of other matrix components including cellular fibronectin and proteoglycans 40 .

Connective tissue growth factor (CTGF/CCN2) is also a potent fibrogenic signal towards stellate cells ${ }^{41,} 42$ and may be upregulated by hyperglycemia and hyperinsulinemia 43 . While stimulation of CTGF production has traditionally been considered TGF $\beta$-dependent 44 , there is also TGF $\beta$-independent regulation ${ }^{45}$.

Contractility-The collagenous bands typical of end-stage cirrhosis contain large numbers of activated stellate cells that contribute to contractility of cells and the entire organ 46 . These impede portal blood flow by constricting individual sinusoids and by contracting the cirrhotic liver. Endothelin-1 and nitric oxide are major counter-regulators controlling stellate cell contractility, in addition to a growing list of additional mediators including angiotensinogen II, eicosanoids, atrial natriueretic peptide, somatostatin and carbon monoxide, among others (see 46, 47 for reviews). As stellate cells activate, the expression of the cytoskeletal protein $\alpha$-SMA is increased which confers increased contractile potential.

Matrix degradation-Fibrosis reflects a balance between matrix production and degradation. The degradation of extracellular matrix is a key event in hepatic fibrosis. Early 
disruption of the normal hepatic matrix by matrix-degrading proteases hastens its replacement by scar matrix, which has deleterious effects on cell function.

A major determinant of progressive fibrosis is failure to degrade the increased interstitial, or scar matrix. Matrix metalloproteinase-1 (MMP-1) is the main protease that can degrade type I collagen, the principal collagen in fibrotic liver. Sources of this enzyme are not as clearly established as for the type IV collagenases. Stellate cells express MMP-1 mRNA but little enzyme can be detected ${ }^{48}$.

Regulation of matrix metalloproteinase activity occurs at many levels, among which is their inactivation by binding to tissue inhibitors of metalloproteinases (TIMPs) ${ }^{49}$. Stellate cells also produce functional TIMP-1 and TIMP-250, and sustained production of these proteins during liver injury could inhibit the activity of interstitial collageneases, leading to reduced degradation of the accumulating matrix during liver injury. TIMP-1 also is anti-apoptotic towards stellate cells51, and thus its sustained expression in liver injury will enlarge the population of activated stellate cells by preventing their clearance. In support of TIMP's role in vivo, transgenic overexpression of TIMP-1 in liver, delays regression of liver fibrosis in experimental animals ${ }^{52}$. Thus, as described below, TIMP antagonism represents a very appealing antifibrotic target.

Stellate cells express uroplasminogen activator receptor (uPA-R) and its inhibitor (PAI-1), as well as other components of the plasmin system ${ }^{53,} 54$. These findings suggest that stellate cells contain most, if not all of the molecules necessary to either activate or inhibit metalloproteinases.

\section{Retinoid loss}

Activation of stellate cells is accompanied by the loss of the characteristic perinuclear retinoid (vitamin A) droplets. In culture, retinoid is stored as retinyl esters whereas the form of retinoid released outside the cell during activation is retinol, suggesting that there is intracellular hydrolysis of esters prior to export ${ }^{55}$. Interesting, mice genetically deficient in lecithin:retinol acyltransferase (LRAT) lack lipid droplets in their stellate cells, but it is unknown what impact this has on the fibrogenic potential 56. Thus, whether retinoid loss is required for stellate cells to activate, and which retinoids might accelerate or prevent activation are not clarified.

\section{Resolution}

As attention has turned to the treatment of liver fibrosis, the issue of how stellate cell activation resolves has become quite critical ${ }^{57,58}$. Two potential pathways account for reduction in activated stellate cells, either reversion to a quiescent phenotype or clearance through apoptosis or senescence.

A large amount of evidence supports the importance of stellate cell apoptosis during regression of liver fibrosis 49, 59. In culture, stellate cells are sensitive to CD95-L and TRAIL-mediated apoptosis, and NK cells can induce apoptosis of stellate cells by a TRAIL mediated mechanism ${ }^{60}$. Nerve growth factor (NGF) derived from hepatocytes is also apoptotic towards stellate cells 61 , and is antagonized by serotonin receptor signaling 62 .

Natural killer cells may be an important determinant of stellate cell apoptosis and fibrosis regression. The anti-fibrotic role of NK cells is also consistent with the clinical data of increased liver fibrosis in the setting of therapeutic immunosuppression. The effect of single immunosuppressive agents on NK cell function is minimal, but the combination of cyclosporine and corticosteroids results in significant loss of NK cell cytotoxicity ${ }^{63}$. 
A recent study has documented that stellate cells also undergo senescence during fibrosis regression, rendering them more susceptible to attack by NK cells ${ }^{64}$. This observation prevents new opportunities to exploit known pathways of cellular senescence to define new therapies and to understand the role of senescence in non-malignant diseases ${ }^{65}$. Presently it is uncertain, however, whether the same stellate cells that express senescence markers are also undergoing apoptosis, as the two pathways typically represent distinct molecular programs.

\section{Therapies for Hepatic Fibrosis - Current and Future}

Points of attack against hepatic fibrosis are derived from our current understanding of liver injury, inflammation and stellate cell activation. The ideal therapies will be those that are orally available, well tolerated during chronic usage, and do not simply prevent progression of fibrosis, but rather regress scar, leading to stabilization or improvement in liver function. While specific therapies developed solely for hepatic fibrosis are attractive, in reality there may be many existing therapies developed for other indications, with well-established safety profiles whose mechanism of action may also be anti-fibrotic. Examples of this group include angiotensin converting enzyme 1 inhibitors and angiotensin receptor blockers, antioxidants, and receptor tyrosine kinase antagonists, among others.

In addition to broadly active oral therapies, monoclonal antibodies and other parenteral therapies may also prove valuable, as these reagents have amassed a solid safety and efficacy profile in a number of chronic diseases when used in weekly or monthly infusions. Moreover, efforts to target therapies specifically to activated stellate cells have begun to succeed. In particular, a study using a vitamin A-containing liposome to deliver an siRNA to a collagen heat shock protein (Hsp47) has shown remarkable specificity in three different animal models of liver fibrosis ${ }^{1}, 66$. This impressive stellate cell targeting could be exploited for a range of therapies to limit collateral injury to other cell types, or to deliver diagnostic imaging agents to liver.

The broad targets of anti-fibrotic therapy can be divided among several categories: a) Cure the primary disease to prevent injury. b) Reduce inflammation or the host response in order to avoid stimulating stellate cell activation. c) 'hepatoprotection' to reduce hepatocyte injury, thereby attenuating downstream signals of activation to stellate cells d) Directly downregulate stellate cell activation. e) Neutralize proliferative, fibrogenic, contractile and/or proinflammatory responses of stellate cells. f) Stimulate apoptosis of stellate cells. g) Increase the degradation of scar matrix, either by stimulating cells that produce matrix proteases, downregulating their inhibitors, or by direct administration of matrix proteases.

\section{a. Cure the Primary Disease}

Clearing the primary cause of liver disease remains to date the most effective 'anti-fibrotic', and increasing evidence in viral liver disease suggests that viral clearance or suppression not only improves histology but also may reduce portal pressure ${ }^{67}$. Other conditions where controlling the primary diseases has salutary effects include abstinence in alcoholic liver disease, removal of excess iron or copper in precirrhotic genetic hemochromatosis or Wilson's, clearance of $\mathrm{HBV}$ or $\mathrm{HCV}$ in chronic viral hepatitis, eradication of organisms in schistosomiasis, or decompression in mechanical bile duct obstruction. Most recently weight loss in patients with NASH has led to reduced fibrogenesis ${ }^{68,69}$.

\section{b. Reduce inflammation and immune response}

Reduced fibrosis has been reported in HCV patients successfully treated with peglyated $\alpha$ interferon and ribavirin ${ }^{70}$, presumably through its effect on viral replication and liver injury. Sustained viral clearance has been associated with marked regression of fibrosis, so that long 
term follow-up of patients successfully cleared of HCV may show more dramatic reversal of disease than at early time points. Importantly, some anti-fibrotic effect is observed even in the absence of viral clearance ${ }^{71}$. In experimental biliary fibrosis $\alpha$-interferon also reduces fibrosis ${ }^{72}$, raising the possibility of a direct anti-fibrotic mechanism in addition to its anti-viral effect. However, to date long term studies of 'interferon maintenance' in the absence of antiviral clearance have not yet proven beneficial.

A number of agents have anti-inflammatory activity in vitro and in vivo which may reduce the stimuli to stellate cell activation. Corticosteroids have been used for decades to treat several types of liver disease, in particular autoimmune hepatitis ${ }^{73}$. Antagonists to TNF $\alpha$, or NFkB modulators have some rationale, as do a growing number of biologically active agents currently used in other chronic inflammatory diseases, in particular inflammatory liver disease. Pentoxyphylline may exert its anti-fibrotic activity by downregulating TNF $\alpha$ signaling ${ }^{74}$.

The renin-angiotensin system may also amplify inflammation through generation of oxidant stress, and therefore either angiotensin converting enzyme antagonists and/or angiotensinogen II type I receptor antagonists may have an anti-inflammatory as well as antifibrogenic activity 75,76 .

Ursodeoxycholic acid has a beneficial effect on fibrosis in primary biliary cirrhosis ${ }^{77}, 78$, possibly in part due to its anti-inflammatory activity. Similarly, a nitric-oxide releasing derivative of ursodeoxycholic acid reduces inflammation, fibrosis and portal pressure in an animal model ${ }^{79}$. More, recently ligands of the FXR receptor have been developed which enhance choleresis and are anti-fibrotic in animal models ${ }^{80}$; clinical trials of these agents are expected in the coming years.

\section{c. Hepatoprotection}

A new class of drugs, broadly referred to as 'hepatoprotectants', are showing considerable promise in pre-clinical and clinical studies, including hepatocyte growth factor (HGF), HGF deletion variants, and HGF synthetic mimetics ${ }^{81-83}$, as well as insulin-like growth factor 84 , and a small molecule caspase inhibitor that improves AST levels in patients with chronic $\mathrm{HCV}$ and is currently in clinical trials 85 .

HGF-There is strong support for the anti-fibrotic effect of HGF in animal models of fibrosis 86, 87. Mechanisms of its anti-fibrotic activity include suppressing TGF $\beta$ expression ${ }^{82}$ and inducing collagenase expression ${ }^{88}$. Further studies have shown growth inhibition and apoptosis of HSCs, as well as blocking biliary epithelial cells from undergoing epithelial-tomesenchymal transition ${ }^{81}$. More recently, a mechanism was uncovered by which HGF inhibits TGF $\beta$ from activating its downstream targets, thereby suppressing TGF $\beta$ mediated transcription of collagen type I in activated HSCs. This effect is mediated by increased interaction between galectin-7 and phosphorylated Smad3, effectively sequestering the pSmad3 to the cytoplasm and preventing collagen promoter activation 89 .

Caspase inhibitors-Apoptosis of hepatocytes is recognized as an inflammatory stimulus that is pro-fibrogenic $15,90-92$. As a result, small molecules have been developed that specifically block caspases, key intracellular effectors of apoptotic signaling ${ }^{93}$. These agents are currently in clinical trials. The main theoretical concern is that by blocking this pathway that removes cells that may have acquired DNA damage, there will be an enhanced risk of malignancy.

FXR ligands-Farnesoid X Receptor, FXR, is a member of the nuclear receptor transcription factor family, which can be activated by binding of bile acids, of which chenodoxycholic acid (CDCA) is the most active endogenous ligand. FXR has been implicated in regulating genes 
controlling bile flow and secretion ${ }^{94} 95$. An additional, novel role for FXR was uncovered with its identification in stellate cells, where it downregulates cellular activation 80. In these studies, the endogenous FXR ligand, CDCA showed a significant anti-fibrotic effect in animal models. In vivo and in vitro evidence suggested that FXR ligands upregulate SHP in HSCs, and markedly reduce collagen I levels 80 . Furthermore, the FXR-SHP cascade effectively inhibits TIMP-1 expression in stellate cells, mediated by interaction of SHP with JunD, resulting in the inability of JunD to bind the TIMP-1 promoter. MMP-2 activity levels are also increased by $100 \%{ }^{96}$. The inhibition of TIMP-1 is pivotal for two reasons: first, metalloprotease activity will no longer be inhibited, and second stellate cells lose the crucial survival signals they receive from TIMP-1 (see above). Interestingly, FXR ligands can reverse the down regulation of PPAR $\gamma$ in stellate cells in models of rodent liver fibrosis (porcine serum, $\mathrm{CCl}_{4}$ and bile duct ligation), and submaximal effective doses of PPAR $\gamma$ agonists and FXR ligands synergistically reduce levels of collagen type I ${ }^{97}$. Combination targeting of these two pathways could reduce the likelihood of side effects resulting from higher doses of a PPAR $\gamma$ agonist.

\section{d. Inhibit Stellate Cell Activation}

Reducing the transformation of quiescent stellate cells to activated myofibroblasts is a particularly attractive target given its central role in the fibrotic response. The most practical approach is to reduce oxidant stress, which is an important stimulus to activation. Antioxidants, including alpha-tocopherol (vitamin E) suppress fibrogenesis in some ${ }^{98}$, but not all 99 studies of experimental fibrogenesis. Other anti-oxidants also can reduce stellate cell activation in culture 100, which provides a rationale for anti-oxidant trials in humans, although as noted above, more potent formulations than those currently available may be required.

Cannabinoids have emerged as a very attractive pathway for antagonizing hepatic fibrosis. There are two identified cannabinoid G-protein-coupled receptors (CB1 and CB2), and studies in human stellate cells demonstrate that activation of CB2 is anti fibrogenic ${ }^{101}$. Stimulation of cultured stellate cells with an endogenous cannabinoid, anandamide, provokes stellate cell death, albeit through a CB2 ligand-independent pathway 102. Moreover, CB1 receptor is induced primarily in hepatic stellate cells as they activate into myofibroblasts during liver injury. Antagonism of this receptor in an acute model of injury due to $\mathrm{CCl}_{4}$ or in isolated cells leads to decreased expression of TGF $\beta 1$, the most potent fibrogenic cytokine, reduced cellular proliferation and increased myofibroblast apoptosis, all of which would effectively reduce fibrosis ${ }^{103}$. Currently, the drug rimonabant, a CB1 antagonist ${ }^{104}$, is undergoing clinical trials in non-alcoholic fatty liver, and a potential anti-fibrotic effect is being monitored in these trials. In contrast to CB1 signaling, the CB2 pathway is anti-fibrotic ${ }^{101}$, and thus agonists rather than antagonists to this pathway can reduce collagen accumulation in animal models ${ }^{105}$.

Interestingly, endogenous opioids, like cannabinoids have profibrogenic activity ${ }^{106}$. Thus, opioid antagonists have been examined in animal models, where they demonstrate anti-fibrotic activity 107 .

The cytokine $\gamma$ interferon has inhibitory effects on stellate cell activation in animal models of fibrosis ${ }^{108}$. A clinical trial of $\gamma$ interferon did not show the expected anti-fibrotic benefit in patients with $\mathrm{HCV}$, possibly because only patients with advanced fibrosis were enrolled and the treatment period (one year) may have been too short. In contrast, a beneficial effect of $\gamma$ interferon was reported in patients with hepatitis B infection ${ }^{109}$.

PPAR $\gamma$ nuclear receptors are expressed in stellate cells, and synthetic PPAR $\gamma$ ligands (thiazolidinediones) down-regulate stellate cell activation ${ }^{110}, 111$. Given their widespread use in diabetes, clinical trials of $2^{\text {nd }}$ and $3^{\text {rd }}$ generation thiazolidinediones (ie., lacking the 
hepatotoxicity seen with $1^{\text {st }}$ generation agents such as troglitazone) are now being tested in clinical trials both in NASH and other fibrotic liver diseases.

Leptin is produced by activated stellate cells ${ }^{112}$, which not only affects lipid metabolism, but also can directly influence wound healing. In fact, animals deficient in leptin have reduced hepatic injury and fibrosis ${ }^{113,114}$. Based on this finding, the discovery of adiponectin, a natural counter-regulator to leptin, may lead to use of this agent in fibrosis, particularly associated with NASH 115,116 .

\section{e. Neutralize proliferative, fibrogenic, contractile and/or pro-inflammatory responses of stellate cells}

Many proliferative cytokines including PDGF, FGF and TGF $\alpha$ signal through tyrosine kinase receptors, inhibitors of which are already undergoing clinical trials in other tissues ${ }^{117}$. Because the intracellular signaling pathways for these receptors are well understood, inhibitors to signaling molecules are being explored in vivo or in cultured stellate cells. Antagonists to a range of pathways are under evaluation that block PDGF ${ }^{118,} 119$ or VEGF receptors ${ }^{120}$, and compounds that modulate intracellular cyclic AMP ${ }^{121}$ or block ion transporters ${ }^{122}$.

The recent success in developing Gleevec a safe, effective small molecule tyrosine kinase antagonist in human leukemia and mesenchymal cell tumors 123,124 augurs well for the potential of this approach in other indications, including liver fibrosis. In fact, Gleevec is antifibrotic in experimental liver fibrosis ${ }^{125}$, albeit only in ongoing rather than established fibrosis ${ }^{126}$. Moreover, combinations of Gleevec with other anti-fibrotics may be possible ${ }^{118}$. Other orally available, low molecular weight small molecules are under development to block cytokine receptor or intracellular signaling. One such compound is a selective inhibitor of Rhomediated focal adhesions, which can reduce experimental liver fibrosis ${ }^{127}$. Antisense to PDGF $\mathrm{B}$ chain also blocks experimental hepatic fibrosis ${ }^{128}$. Since siRNA technology is increasingly become clinically applicable ${ }^{66}$, this approach merits further evaluation.

Inhibition of matrix production has been the primary target of most anti-fibrotic therapies to date. This has been attempted directly by blocking matrix synthesis and processing, or indirectly by inhibiting the activity of TGF $\beta 1$, the major fibrogenic cytokine. The emerging importance of translational regulation of collagen gene expression ${ }^{129-132}$ could lead to specific translational inhibitors with therapeutic value. Colchicine generated excitement at one time because of its apparent efficacy in a small group of patients ${ }^{133}$; however, a more recent study in alcoholic cirrhosis showed no benefit ${ }^{134}$.

TGF $\beta$ antagonists are being extensively tested because neutralizing this potent cytokine would have the dual effect of inhibiting matrix production and accelerating its degradation. Animal and culture studies using soluble TGF $\beta$ receptors or other means of neutralizing the cytokine including monoclonal antibodies and protease inhibitors to block TGF $\beta$ activation, have established proof-of-principle for these approaches ${ }^{135-137}$. Moreover, the natural compound curcumin may also block TGF $\beta$ signaling ${ }^{138,139}$. Concerns that inhibiting TGF $\beta$ may alter hepatocellular growth or apoptosis will need to be addressed as these antagonists reach clinical trials, but in other tissues there is great promise for this approach. A number of even newer TGF $\beta$ antagonists are also being developed and may undergo testing soon. These could include recombinant Smad7, which antagonizes TGF $\beta$ activity in stellate cells ${ }^{140}$.

As described above, a recent study elegantly employed liposomes containing both vitamin A and an siRNA against the collagen chaperone HSP47 to attack collagen production by stellate cells ${ }^{66}$. Incorporation of vitamin A in the liposomal complex greatly enhanced their specificity for stellate cells, which serve as the primary site of storage for dietary vitamin A (retinoid). Levels of $\mathrm{Hsp} 47$ in the endoplasmic reticulum have previously been shown to correlate closely 
with collagen production, and its expression in the liver is localized to activated collagen producing stellate cells ${ }^{141,} 142$.

Rapamycin, an immunosuppressive drug used following liver transplantation has the added benefit of inhibiting stellate cell proliferation ${ }^{143}$, which could attenuate the accelerated fibrosis progression in patients with recurrent $\mathrm{HCV}$; however, enthusiasm for using rapamycin has been tempered by a reported increase in hepatic artery thrombosis ${ }^{144}$.

Relaxin, a natural peptide hormone that mediates parturition, has been developed as an agent to decrease collagen synthesis by stellate cells and increase matrix degradation in vitro and in vivo ${ }^{145}$. Stellate cells also express relaxin receptors ${ }^{146}$, which might represent an attractive target.

Because endothelin- 1 is an important regulator of wound contraction and blood flow regulation mediated by stellate cells, antagonists have been tested as both Anti-fibrotic and portal hypotensive agents. Bosentan, a mixed endothelin A \& B receptor antagonist, has Anti-fibrotic activity and reduces stellate cell activation in experimental hepatic fibrosis ${ }^{147}$. This and other endothelin antagonists remain attractive drug development targets ${ }^{148}$. Alternatively, delivery of nitric oxide to injured liver may have the same therapeutic effect as inhibiting endothelin-1 ${ }^{79,} 149$.

\section{f. Stimulate stellate cell apoptosis}

Apoptosis is the main mechanism accounting for reduced stellate cell numbers during spontaneous recovery from liver injury 59, 150, with recent data (noted above) implicating senescence as well. A combination of signaling pathways may be involved in inducing this apoptosis, thereby clearing fibrogenic cells from the injury mileu. Pro-apoptotic activity towards stellate cells will need to be restricted to this cell type to avoid collateral loss of hepatocytes or other non-parenchymal cells. Below are several examples of how this could be achieved:

TIMP antagonism (see above) - TIMP-1 plays an important role in stellate cell survival by directly inhibiting apoptosis of these cells. The pro-survival effect of TIMP-1 is dependent on MMP inhibition ${ }^{51}$. Transgenic over expression of TIMP-1 in mouse models of fibrosis leads to delayed regression, and is accompanied by decreased numbers of apoptotic stellate cells ${ }^{52}$. On the contrary, antibodies to TIMP can attenuate fibrosis ${ }^{151}$. Similarly, use of MMP-9 mutants proteins to sequester TIMP-1 molecules reduces fibrosis accumulation by enhancing matrix resorption 152 .

NK cell stimulation/immunomodulation - NK cells are members of the innate immune system and account for $50 \%$ of the lymphoid pool in the liver. In addition to aiding in defense against viral infections, NK cells can ameliorate hepatic fibrosis by killing activated stellate cells 60,153 , associated with the release of two anti-fibrotic cytokines IFN $\alpha$ and $\gamma$ interferon 108,154 . Interestingly, alcohol has a dampening effect on these anti-fibrotic qualities of NK cells, which could account for the accelerated fibrosis in the setting of alcoholic liver disease 155. Thus, new approaches to anti-fibrotic therapies could exploit strategies that foster and promote NK cell surveillance, or activate downstream signaling pathways that NK cells use to abolish activated stellate cells.

Pro-apoptotic therapeutics targeted to stellate cells-Attention is increasingly focused on how liver fibrosis regresses, and in particular the fate of activated stellate cells as fibrosis recedes. Mounting evidence indicates that both reversal of the activated stellate cell phenotype and apoptosis are possible. In particular, as liver fibrosis is decreased there is selective cell death of activated stellate cells ${ }^{150}$. This exciting observation has led to animal 
studies using gliotoxin, which provokes selective apoptosis of stellate cells in culture and in

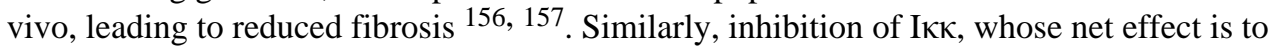
increase NFKB signaling in stellate cells, may accelerate apoptosis ${ }^{158}$. Apoptosis can also be provoked by disruption of integrin-mediated adhesion ${ }^{159}$ or through use of TRAIL ligands 160. Stellate cells contain several families of apoptotic mediators, including Fas/FasL, TNF receptors, nerve growth factor receptors ${ }^{61}$, and $\mathrm{Bcl} / \mathrm{Bax}$, so that additional targets to promote apoptosis will likely be uncovered in the future ${ }^{161}$.

\section{f. Increase the degradation of scar matrix}

This component of treatment is very important, because anti-fibrotic therapy in human liver disease will need to provoke resorption of existing matrix in addition to preventing deposition of new scar. Direct expression of metalloproteinases in animal models of hepatic fibrosis has begun to confirm that matrix can be resorbed by expression of exogenous enzymes ${ }^{162,163}$. In addition, an experimental study has affirmed the importance of matrix degradation in the regression of hepatic fibrosis by demonstrating that a genetically altered mouse expressing mutant collagen resistant to degradation displays delayed regression of fibrosis following liver injury 164 .

\section{Expert Commentary}

A new field of liver-directed therapies for chronic fibrosing liver disease is about to emerge. With continued elucidation of pathways of both matrix production and degradation in liver injury, new targets are steadily accruing. Combined with enthusiasm for this new 'market' by biotechnology and pharmaceutical companies, the future is extremely bright for this nascent field. Nonetheless, more robust biomarkers and clinical trial endpoints must be validated to allow these agents to establish their efficacy. Combined with emerging genetic markers of disease risk, clinical trials are likely to be progressively shorter and more accurate in establishing therapeutic benefit by focusing on patients at high risk of progression, using endpoints that change rapidly and reproducibly in response to an effective drug. Once efficacy is established in liver, many new agents are likely to be tested in other chronic fibrotic diseases, including those in lung, kidney, pancreas, heart and bone marrow, among others.

\section{Five-year view}

A major turning point in the establishment of this new field of fibrosis therapies will be the completion of a successful proof-of-principle trial within five years, showing clear-cut efficacy in patients with ongoing chronic liver injury. Once this occurs, a flood of new therapies are likely to enter clinical trials. While these are unlikely to be available to the practitioner within 5 years, in the subsequent 5 years, they will be transformative in managing patients with chronic liver disease, sparing many from the need for liver transplantation and possibly reducing the risk of hepatocellular carcinoma, the third leading cause of cancer mortality worldwide.

\section{Key Issues}

- Fibrogenic stimuli in liver include reactive oxygen species, hypoxia, inflammatory and immune responses, apoptosis and steatosis.

- Most therapies are focused on targeting hepatic injury and activated stellate cells, which are the primary source of ECM deposition.

- Pathways regulating different features of stellate cell activation including proliferation, contractility, and ECM production provide a useful template for identifying therapeutic targets. 
- A variety of approaches have been successful in attenuating fibrosis in animal models using the above-mentioned pathways, but these need to be tested in human trials. Directly targeting accumulated fibrotic matrix with protease activity merits further development.

- There is a great need to identify effective and unequivocal end-points for antifibrotic drugs in humans that are dynamic and specific in order to translate the exciting data from animal models to patients.

\section{References}

1. Friedman SL. Mechanisms of hepatic fibrogenesis. Gastroenterology 2008;134(6):1655-1669. [PubMed: 18471545]

2. Svegliati Baroni G, D'Ambrosio L, Ferretti G, et al. Fibrogenic effect of oxidative stress on rat hepatic stellate cells. Hepatology 1998;27(3):720-726. [PubMed: 9500700]

3. Galli A, Svegliati-Baroni G, Ceni E, et al. Oxidative stress stimulates proliferation and invasiveness of hepatic stellate cells via a MMP2-mediated mechanism. Hepatology 2005;41(5):1074-1084. [PubMed: 15841469]

4. Ankoma-Sey V, Wang Y, Dai Z. Hypoxic stimulation of vascular endothelial growth factor expression in activated rat hepatic stellate cells. Hepatology 2000;31(1):141-148. [PubMed: 10613739]

5. Corpechot C, Barbu V, Wendum D, et al. Hypoxia-induced VEGF and collagen I expressions are associated with angiogenesis and fibrogenesis in experimental cirrhosis. Hepatology 2002;35(5): 1010-1021. [PubMed: 11981751]

6. Jeong WI, Do SH, Yun HS, et al. Hypoxia potentiates transforming growth factor-beta expression of hepatocyte during the cirrhotic condition in rat liver. Liver Int 2004;24(6):658-668. [PubMed: 15566519]

7. Mehal, WZ.; Friedman, SL. The role of inflammation and immunity in the pathogenesis of liver fibrosis. In: Gershwin, ME.; Veirling, JM.; Manns, MP., editors. Liver Immunology. Totowa, New Jersey: Humana Press; 2007. p. 99-109.

8. Henderson NC, Iredale JP. Liver fibrosis: cellular mechanisms of progression and resolution. Clin Sci (Lond) 2007;112(5):265-280. [PubMed: 17261089]

9. Mehal WZ. Activation-induced cell death of hepatic stellate cells by the innate immune system. Gastroenterology 2006;130(2):600-603. [PubMed: 16472612]

10. Gao B, Jeong WI, Tian Z. Liver: An organ with predominant innate immunity. Hepatology 2008;47 (2):729-736. [PubMed: 18167066]

11. Szabo G, Mandrekar P, Dolganiuc A. Innate immune response and hepatic inflammation. Semin Liver Dis 2007;27(4):339-350. [PubMed: 17979071]

12. Steib CJ, Gerbes AL, Bystron M, et al. Kupffer cell activation in normal and fibrotic livers increases portal pressure via thromboxane A(2). J Hepatol 2007;47(2):228-238. [PubMed: 17573142]

13. Canbay A, Taimr P, Torok N, Higuchi H, Friedman S, Gores GJ. Apoptotic body engulfment by a human stellate cell line is profibrogenic. Lab Invest 2003;83(5):655-663. [PubMed: 12746475]

14. Zhan SS, Jiang JX, Wu J, et al. Phagocytosis of apoptotic bodies by hepatic stellate cells induces NADPH oxidase and is associated with liver fibrosis in vivo. Hepatology 2006;43(3):435-443. [PubMed: 16496318]

15. Canbay A, Friedman S, Gores GJ. Apoptosis: the nexus of liver injury and fibrosis. Hepatology 2004;39(2):273-278. [PubMed: 14767974]

16. Fartoux L, Poujol-Robert A, Guechot J, Wendum D, Poupon R, Serfaty L. Insulin resistance is a cause of steatosis and fibrosis progression in chronic hepatitis C. Gut 2005;54(7):1003-1008. [PubMed: 15951550]

17. Ekstedt M, Franzen LE, Mathiesen UL, et al. Long-term follow-up of patients with NAFLD and elevated liver enzymes. Hepatology 2006;44(4):865-873. [PubMed: 17006923] 
18. Reeves HL, Burt AD, Wood S, Day CP. Hepatic stellate cell activation occurs in the absence of hepatitis in alcoholic liver disease and correlates with the severity of steatosis. J Hepatol 1996;25(5): 677-683. [PubMed: 8938545]

19. Friedman SL. Liver fibrosis - from bench to bedside. J Hepatol 2003;38 Suppl 1:S38-S53. [PubMed: 12591185]

20. Bilzer M, Roggel F, Gerbes AL. Role of Kupffer cells in host defense and liver disease. Liver Int 2006;26(10):1175-1186. [PubMed: 17105582]

21. Canbay A, Higuchi H, Bronk SF, Taniai M, Sebo TJ, Gores GJ. Fas enhances fibrogenesis in the bile duct ligated mouse: a link between apoptosis and fibrosis. Gastroenterology 2002;123(4):1323-1330. [PubMed: 12360492]

22. Canbay A, Feldstein AE, Higuchi H, et al. Kupffer cell engulfment of apoptotic bodies stimulates death ligand and cytokine expression. Hepatology 2003;38(5):1188-1198. [PubMed: 14578857]

23. Borkham-Kamphorst E, van Roeyen CR, Ostendorf T, Floege J, Gressner AM, Weiskirchen R. Profibrogenic potential of PDGF-D in liver fibrosis. J Hepatol 2007;46(6):1064-1074. [PubMed: 17397961]

24. Wong L, Yamasaki G, Johnson RJ, Friedman SL. Induction of beta-platelet-derived growth factor receptor in rat hepatic lipocytes during cellular activation in vivo and in culture. J Clin Invest 1994;94 (4):1563-1569. [PubMed: 7929832]

25. Lechuga CG, Hernandez-Nazara ZH, Hernandez E, et al. PI3K is involved in PDGF-beta receptor upregulation post-PDGF-BB treatment in mouse HSC. Am J Physiol Gastrointest Liver Physiol 2006;291(6):G1051-G1061. [PubMed: 16990448]

26. Di Sario A, Bendia E, Taffetani $\mathrm{S}$, et al. Selective $\mathrm{Na}+\mathrm{H}+$ exchange inhibition by cariporide reduces liver fibrosis in the rat. Hepatology 2003;37(2):256-266. [PubMed: 12540775]

27. Yoshiji H, Kuriyama S, Yoshii J, et al. Vascular endothelial growth factor and receptor interaction is a prerequisite for murine hepatic fibrogenesis. Gut 2003;52(9):1347-1354. [PubMed: 12912869]

28. Marra F, Grandaliano G, Valente AJ, Abboud HE. Thrombin stimulates proliferation of liver fatstoring cells and expression of monocyte chemotactic protein-1: potential role in liver injury. Hepatology 1995;22(3):780-787. [PubMed: 7657283]

29. Marra F, DeFranco R, Grappone C, et al. Expression of the thrombin receptor in human liver: upregulation during acute and chronic injury. Hepatology 1998;27(2):462-471. [PubMed: 9462645]

30. Steiling H, Muhlbauer M, Bataille F, Scholmerich J, Werner S, Hellerbrand C. Activated hepatic stellate cells express keratinocyte growth factor in chronic liver disease. Am J Pathol 2004;165(4): 1233-1241. [PubMed: 15466389]

31. Yu C, Wang F, Jin C, et al. Role of fibroblast growth factor type 1 and 2 in carbon tetrachlorideinduced hepatic injury and fibrogenesis. Am J Pathol 2003;163(4):1653-1662. [PubMed: 14507672]

32. Ikeda K, Wakahara T, Wang YQ, Kadoya H, Kawada N, Kaneda K. In vitro migratory potential of rat quiescent hepatic stellate cells and its augmentation by cell activation. Hepatology 1999;29(6): 1760-1767. [PubMed: 10347119]

33. Kinnman N, Hultcrantz R, Barbu V, et al. PDGF-mediated chemoattraction of hepatic stellate cells by bile duct segments in cholestatic liver injury. Lab Invest 2000;80(5):697-707. [PubMed: 10830780]

34. Marra F, Romanelli RG, Giannini C, et al. Monocyte chemotactic protein-1 as a chemoattractant for human hepatic stellate cells. Hepatology 1999;29(1):140-148. [PubMed: 9862860]

35. Bonacchi A, Romagnani P, Romanelli RG, et al. Signal transduction by the chemokine receptor CXCR3: activation of Ras/ERK, Src, and phosphatidylinositol 3-kinase/Akt controls cell migration and proliferation in human vascular pericytes. J Biol Chem 2001;276(13):9945-9954. [PubMed: 11136732]

36. Hashmi AZ, Hakim W, Kruglov EA, et al. Adenosine inhibits cytosolic calcium signals and chemotaxis in hepatic stellate cells. Am J Physiol Gastrointest Liver Physiol 2007;292(1):G395G401. [PubMed: 17053161]

37. Melton AC, Yee HF. Hepatic stellate cell protrusions couple platelet-derived growth factor-BB to chemotaxis. Hepatology 2007;45(6):1446-1453. [PubMed: 17465006]

38. Inagaki Y, Okazaki I. Emerging insights into Transforming growth factor beta Smad signal in hepatic fibrogenesis. Gut 2007;56(2):284-292. [PubMed: 17303605] 
39. Breitkopf K, Godoy P, Ciuclan L, Singer MV, Dooley S. TGF-beta/Smad signaling in the injured liver. Z Gastroenterol 2006;44(1):57-66. [PubMed: 16397841]

40. George J, Wang SS, Sevcsik AM, et al. Transforming growth factor-beta initiates wound repair in rat liver through induction of the EIIIA-fibronectin splice isoform. Am J Pathol 2000;156(1):115-124. [PubMed: 10623659]

41. Rachfal AW, Brigstock DR. Connective tissue growth factor (CTGF/CCN2) in hepatic fibrosis. Hepatol Res 2003;26(1):1-9. [PubMed: 12787797]

42. Gao R, Brigstock DR. Connective tissue growth factor (CCN2) induces adhesion of rat activated hepatic stellate cells by binding of its C-terminal domain to integrin alpha(v)beta(3) and heparan sulfate proteoglycan. J Biol Chem 2004;279(10):8848-8855. [PubMed: 14684735]

43. Paradis V, Perlemuter G, Bonvoust F, et al. High glucose and hyperinsulinemia stimulate connective tissue growth factor expression: a potential mechanism involved in progression to fibrosis in nonalcoholic steatohepatitis. Hepatology 2001;34(4 Pt 1):738-744. [PubMed: 11584370]

44. Grotendorst GR. Connective tissue growth factor: a mediator of TGF-beta action on fibroblasts. Cytokine Growth Factor Rev 1997;8(3):171-179. [PubMed: 9462483]

45. Brigstock DR. The CCN family: a new stimulus package. J Endocrinol 2003;178(2):169-175. [PubMed: 12904165]

46. Rockey DC. Vascular mediators in the injured liver. Hepatology 2003;37(1):4-12. [PubMed: 12500181]

47. Reynaert H, Thompson MG, Thomas T, Geerts A. Hepatic stellate cells: role in microcirculation and pathophysiology of portal hypertension. Gut 2002;50(4):571-581. [PubMed: 11889082]

48. Milani S, Herbst H, Schuppan D, et al. Differential expression of matrix-metalloproteinase-1 and -2 genes in normal and fibrotic human liver. Am J Pathol 1994;144(3):528-537. [PubMed: 8129038]

49. Iredale JP. Hepatic stellate cell behavior during resolution of liver injury. Semin Liver Dis 2001;21 (3):427-436. [PubMed: 11586470]

50. Arthur MJ, Fibrogenesis II. Metalloproteinases and their inhibitors in liver fibrosis. Am J Physiol Gastrointest Liver Physiol 2000;279(2):G245-G249. [PubMed: 10915630]

51. Murphy FR, Issa R, Zhou X, et al. Inhibition of apoptosis of activated hepatic stellate cells by tissue inhibitor of metalloproteinase-1 is mediated via effects on matrix metalloproteinase inhibition: implications for reversibility of liver fibrosis. J Biol Chem 2002;277(13):11069-11076. [PubMed: 11796725]

52. Yoshiji H, Kuriyama S, Yoshii J, et al. Tissue inhibitor of metalloproteinases-1 attenuates spontaneous liver fibrosis resolution in the transgenic mouse. Hepatology 2002;36(4 Pt 1):850-860. [PubMed: 12297832]

53. Knittel T, Fellmer P, Ramadori G. Gene expression and regulation of plasminogen activator inhibitor type I in hepatic stellate cells of rat liver. Gastroenterology 1996;111(3):745-754. [PubMed: 8780581]

54. Fiorucci S, Antonelli E, Distrutti E, et al. PAR1 antagonism protects against experimental liver fibrosis. Role of proteinase receptors in stellate cell activation. Hepatology 2004;39(2):365-375. [PubMed: 14767989]

55. Friedman SL, Wei S, Blaner WS. Retinol release by activated rat hepatic lipocytes: regulation by Kupffer cell-conditioned medium and PDGF. Am J Physiol 1993;264(5 Pt 1):G947-G952. [PubMed: 8498521]

56. O'Byrne SM, Wongsiriroj N, Libien J, et al. Retinoid absorption and storage is impaired in mice lacking lecithin:retinol acyltransferase (LRAT). J Biol Chem 2005;280(42):35647-35657. [PubMed: 16115871]

57. Fallowfield JA, Iredale JP. Reversal of liver fibrosis and cirrhosis--an emerging reality. Scott Med J 2004;49(1):3-6. [PubMed: 15012043]

58. Friedman SL, Bansal MB. Reversal of hepatic fibrosis -- fact or fantasy? Hepatology 2006;43(2 Suppl 1):S82-S88. [PubMed: 16447275]

59. Issa R, Williams E, Trim N, et al. Apoptosis of hepatic stellate cells: involvement in resolution of biliary fibrosis and regulation by soluble growth factors. Gut 2001;48(4):548-557. [PubMed: $11247901]$ 
60. Radaeva S, Sun R, Jaruga B, Nguyen VT, Tian Z, Gao B. Natural killer cells ameliorate liver fibrosis by killing activated stellate cells in NKG2D-dependent and tumor necrosis factor-related apoptosisinducing ligand-dependent manners. Gastroenterology 2006;130(2):435-452. [PubMed: 16472598]

61. Oakley F, Trim N, Constandinou CM, et al. Hepatocytes express nerve growth factor during liver injury: evidence for paracrine regulation of hepatic stellate cell apoptosis. Am J Pathol 2003;163(5): 1849-1858. [PubMed: 14578185]

62. Ruddell RG, Oakley F, Hussain Z, et al. A role for serotonin (5-HT) in hepatic stellate cell function and liver fibrosis. Am J Pathol 2006;169(3):861-876. [PubMed: 16936262]

63. Hudnall SD. Cyclosporin A renders target cells resistant to immune cytolysis. Eur J Immunol 1991;21 (1):221-226. [PubMed: 1846819]

64. Krizhanovsky V, Yon M, Dickins RA, et al. Senescence of activated stellate cells limits liver fibrosis. Cell 2008;134(4):657-667. [PubMed: 18724938]

65. Green MR. Senescence: not just for tumor suppression. Cell 2008;134(4):562-564. [PubMed: 18724927]

66. Sato Y, Murase K, Kato J, et al. Resolution of liver cirrhosis using vitamin A-coupled liposomes to deliver siRNA against a collagen-specific chaperone. Nat Biotechnol 2008;26(4):431-442. [PubMed: 18376398]

67. Roberts S, Gordon A, McLean C, et al. Effect of sustained viral response on hepatic venous pressure gradient in hepatitis C-related cirrhosis. Clin Gastroenterol Hepatol 2007;5(8):932-937. [PubMed: 17544878]

68. Dixon JB, Bhathal PS, Hughes NR, O'Brien PE. Nonalcoholic fatty liver disease: Improvement in liver histological analysis with weight loss. Hepatology 2004;39(6):1647-1654. [PubMed: 15185306]

69. Klein S, Mittendorfer B, Eagon JC, et al. Gastric bypass surgery improves metabolic and hepatic abnormalities associated with nonalcoholic fatty liver disease. Gastroenterology 2006;130(6):15641572. [PubMed: 16697719]

70. Poynard T, McHutchison J, Manns M, et al. Impact of pegylated interferon alfa- $2 \mathrm{~b}$ and ribavirin on liver fibrosis in patients with chronic hepatitis C. Gastroenterology 2002;122(5):1303-1313. [PubMed: 11984517]

71. Shiratori Y, Imazeki F, Moriyama M, et al. Histologic improvement of fibrosis in patients with hepatitis $C$ who have sustained response to interferon therapy. Ann Intern Med 2000;132(7):517524. [PubMed: 10744587]

72. Moreno MG, Muriel P. Remission of liver fibrosis by interferon-alpha $2 \mathrm{~b}$. Biochem Pharmacol 1995;50(4):515-520. [PubMed: 7646558]

73. Czaja AJ, Carpenter HA. Progressive fibrosis during corticosteroid therapy of autoimmune hepatitis. Hepatology 2004;39(6):1631-1638. [PubMed: 15185304]

74. Raetsch C, Jia JD, Boigk G, et al. Pentoxifylline downregulates profibrogenic cytokines and procollagen I expression in rat secondary biliary fibrosis. Gut 2002;50(2):241-247. [PubMed: 11788567]

75. Ramalho LN, Ramalho FS, Zucoloto S, et al. Effect of losartan, an angiotensin II antagonist, on secondary biliary cirrhosis. Hepatogastroenterology 2002;49(48):1499-1502. [PubMed: 12397717]

76. Kurikawa N, Suga M, Kuroda S, Yamada K, Ishikawa H. An angiotensin II type 1 receptor antagonist, olmesartan medoxomil, improves experimental liver fibrosis by suppression of proliferation and collagen synthesis in activated hepatic stellate cells. Br J Pharmacol 2003;139(6):1085-1094. [PubMed: 12871826]

77. Degott C, Zafrani ES, Callard P, Balkau B, Poupon RE, Poupon R. Histopathological study of primary biliary cirrhosis and the effect of ursodeoxycholic acid treatment on histology progression. Hepatology 1999;29(4):1007-1012. [PubMed: 10094939]

78. Pares A, Rodes J. Natural history of primary biliary cirrhosis. Clin Liver Dis 2003;7(4):779-794. [PubMed: 14594131]

79. Fiorucci S, Antonelli E, Morelli A. Nitric oxide and portal hypertension: a nitric oxide-releasing derivative of ursodeoxycholic actd that selectively releases nitric oxide in the liver. Dig Liver Dis 2003;35 Suppl:61-69. [PubMed: 12725611] 
80. Fiorucci S, Antonelli E, Rizzo G, et al. The nuclear receptor SHP mediates inhibition of hepatic stellate cells by FXR and protects against liver fibrosis. Gastroenterology 2004;127(5):1497-1512. [PubMed: 15521018]

81. Kim WH, Matsumoto K, Bessho K, Nakamura T. Growth inhibition and apoptosis in liver myofibroblasts promoted by hepatocyte growth factor leads to resolution from liver cirrhosis. Am J Pathol 2005;166(4):1017-1028. [PubMed: 15793283]

82. Ueki T, Kaneda Y, Tsutsui H, et al. Hepatocyte growth factor gene therapy of liver cirrhosis in rats. Nat Med 1999;5(2):226-230. [PubMed: 9930873]

83. Masunaga H, Fujise N, Shiota A, et al. Preventive effects of the deleted form of hepatocyte growth factor against various liver injuries. Eur J Pharmacol 1998;342(2-3):267-279. [PubMed: 9548396]

84. Sanz S, Pucilowska JB, Liu S, et al. Expression of insulin-like growth factor I by activated hepatic stellate cells reduces fibrogenesis and enhances regeneration after liver injury. Gut 2005;54(1):134141. [PubMed: 15591519]

85. Valentino KL, Gutierrez M, Sanchez R, Winship MJ, Shapiro DA. First clinical trial of a novel caspase inhibitor: anti-apoptotic caspase inhibitor, IDN-6556, improves liver enzymes. Int J Clin Pharmacol Ther 2003;41(10):441-449. [PubMed: 14703949]

86. Matsuda Y, Matsumoto K, Ichida T, Nakamura T. Hepatocyte growth factor suppresses the onset of liver cirrhosis and abrogates lethal hepatic dysfunction in rats. J Biochem (Tokyo) 1995;118(3):643649. [PubMed: 8690730]

87. Yasuda H, Imai E, Shiota A, Fujise N, Morinaga T, Higashio K. Antifibrogenic effect of a deletion variant of hepatocyte growth factor on liver fibrosis in rats. Hepatology 1996;24(3):636-642. [PubMed: 8781336]

88. Ozaki I, Zhao G, Mizuta T, et al. Hepatocyte growth factor induces collagenase (matrix metalloproteinase- 1) via the transcription factor Ets-1 in human hepatic stellate cell line. J Hepatol 2002;36(2):169-178. [PubMed: 11830328]

89. Inagaki Y, Higashi K, Kushida M, et al. Hepatocyte growth factor suppresses profibrogenic signal transduction via nuclear export of Smad3 with galectin-7. Gastroenterology 2008;134(4):1180-1190. [PubMed: 18395096]

90. Feldstein A, Gores GJ. Steatohepatitis and apoptosis: therapeutic implications. Am J Gastroenterol 2004;99(9):1718-1719. [PubMed: 15330908]

91. Feldstein AE, Canbay A, Angulo P, et al. Hepatocyte apoptosis and fas expression are prominent features of human nonalcoholic steatohepatitis. Gastroenterology 2003;125(2):437-443. [PubMed: 12891546]

92. Canbay A, Kip SN, Kahraman A, Gieseler RK, Nayci A, Gerken G. Apoptosis and fibrosis in nonalcoholic fatty liver disease. Turk J Gastroenterol 2005;16(1):1-6. [PubMed: 16252180]

93. Canbay A, Feldstein A, Baskin-Bey E, Bronk SF, Gores GJ. The caspase inhibitor IDN-6556 attenuates hepatic injury and fibrosis in the bile duct ligated mouse. J Pharmacol Exp Ther 2004;308 (3):1191-1196. [PubMed: 14617689]

94. Zhang Y, Edwards PA. FXR signaling in metabolic disease. FEBS Lett 2008;582(1):10-18. [PubMed: 18023284]

95. Rader DJ. Liver X receptor and farnesoid X receptor as therapeutic targets. Am J Cardiol 2007;100 (11 A):n15-n19. [PubMed: 18047847]

96. Fiorucci S, Rizzo G, Antonelli E, et al. A FXR-SHP regulatory cascade modulates TIMP-1 and MMPs expression in HSCs and promotes resolution of liver fibrosis. J Pharmacol Exp Ther. 2005

97. Fiorucci S, Rizzo G, Antonelli E, et al. Cross-talk between farnesoid-X-receptor (FXR) and peroxisome proliferator-activated receptor gamma contributes to the antifibrotic activity of FXR ligands in rodent models of liver cirrhosis. J Pharmacol Exp Ther 2005;315(1):58-68. [PubMed: 15980055]

98. Pietrangelo A, Borella F, Casalgrandi G, et al. Antioxidant activity of silybin in vivo during longterm iron overload in rats. Gastroenterology 1995;109(6):1941-1949. [PubMed: 7498660]

99. Brown KE, Poulos JE, Li L, et al. Effect of vitamin E supplementation on hepatic fibrogenesis in chronic dietary iron overload. Am J Physiol 1997;272(1 Pt 1):G116-G123. [PubMed: 9038884] 
100. Kawada N, Seki S, Inoue M, Kuroki T. Effect of antioxidants, resveratrol, quercetin, and Nacetylcysteine, on the functions of cultured rat hepatic stellate cells and Kupffer cells. Hepatology 1998;27(5):1265-1274. [PubMed: 9581680]

101. Julien B, Grenard P, Teixeira-Clerc F, et al. Antifibrogenic role of the cannabinoid receptor CB2 in the liver. Gastroenterology 2005;128(3):742-755. [PubMed: 15765409]

102. Siegmund SV, Uchinami H, Osawa Y, Brenner DA, Schwabe RF. Anandamide induces necrosis in primary hepatic stellate cells. Hepatology 2005;41(5):1085-1095. [PubMed: 15841466]

103. Teixeira-Clerc F, Julien B, Grenard P, et al. CB1 cannabinoid receptor antagonism: a new strategy for the treatment of liver fibrosis. Nat Med 2006;12(6):671-676. [PubMed: 16715087]

104. Gelfand EV, Cannon CP. Rimonabant: a selective blocker of the cannabinoid CB1 receptors for the management of obesity, smoking cessation and cardiometabolic risk factors. Expert Opin Investig Drugs 2006;15(3):307-315.

105. Munoz-Luque J, Ros J, Fernandez-Varo G, et al. Regression of fibrosis after chronic stimulation of cannabinoid CB2 receptor in cirrhotic rats. J Pharmacol Exp Ther 2008;324(2):475-483. [PubMed: 18029545]

106. De Minicis S, Candelaresi C, Marzioni M, et al. Role of endogenous opioids in modulating HSC activity in vitro and liver fibrosis in vivo. Gut 2008;57(3):352-364. [PubMed: 17989109]

107. Ebrahimkhani MR, Kiani S, Oakley F, et al. Naltrexone, an opioid receptor antagonist, attenuates liver fibrosis in bile duct ligated rats. Gut. 2006

108. Rockey DC, Chung JJ. Interferon gamma inhibits lipocyte activation and extracellular matrix mRNA expression during experimental liver injury: implications for treatment of hepatic fibrosis. J Investig Med 1994;42(4):660-670.

109. Weng H, Mertens PR, Gressner AM, Dooley S. IFN-gamma abrogates profibrogenic TGF-beta signaling in liver by targeting expression of inhibitory and receptor Smads. J Hepatol 2007;46(2): 295-303. [PubMed: 17125875]

110. Galli A, Crabb DW, Ceni E, et al. Antidiabetic thiazolidinediones inhibit collagen synthesis and hepatic stellate cell activation in vivo and in vitro. Gastroenterology 2002;122(7):1924-1940. [PubMed: 12055599]

111. Marra F, Efsen E, Romanelli RG, et al. Ligands of peroxisome proliferator-activated receptor gamma modulate profibrogenic and proinflammatory actions in hepatic stellate cells. Gastroenterology 2000;119(2):466-478. [PubMed: 10930382]

112. Saxena NK, Titus MA, Ding X, et al. Leptin as a novel profibrogenic cytokine in hepatic stellate cells: mitogenesis and inhibition of apoptosis mediated by extracellular regulated kinase (Erk) and Akt phosphorylation. Faseb J 2004;18(13):1612-1614. [PubMed: 15319373]

113. Saxena NK, Ikeda K, Rockey DC, Friedman SL, Anania FA. Leptin in hepatic fibrosis: evidence for increased collagen production in stellate cells and lean littermates of ob/ob mice. Hepatology 2002;35(4):762-771. [PubMed: 11915021]

114. Ikejima K, Honda H, Yoshikawa M, et al. Leptin augments inflammatory and profibrogenic responses in the murine liver induced by hepatotoxic chemicals. Hepatology 2001;34(2):288-297. [PubMed: 11481614]

115. Ding X, Saxena NK, Lin S, Xu A, Srinivasan S, Anania FA. The roles of leptin and adiponectin: a novel paradigm in adipocytokine regulation of liver fibrosis and stellate cell biology. Am J Pathol 2005;166(6):1655-1669. [PubMed: 15920151]

116. Kamada Y, Tamura S, Kiso S, et al. Enhanced carbon tetrachloride-induced liver fibrosis in mice lacking adiponectin. Gastroenterology 2003;125(6):1796-1807. [PubMed: 14724832]

117. Wiedmann MW, Caca K. Molecularly targeted therapy for gastrointestinal cancer. Curr Cancer Drug Targets 2005;5(3):171-193. [PubMed: 15892618]

118. Yoshiji H, Kuriyama S, Noguchi R, et al. Amelioration of liver fibrogenesis by dual inhibition of PDGF and TGF-beta with a combination of imatinib mesylate and ACE inhibitor in rats. Int J Mol Med 2006;17(5):899-904. [PubMed: 16596278]

119. Gonzalo T, Beljaars L, van de Bovenkamp M, et al. Local inhibition of liver fibrosis by specific delivery of a PDGF kinase inhibitor to hepatic stellate cells. J Pharmacol Exp Ther. 2007 
120. Tugues S, Fernandez-Varo G, Munoz-Luque J, et al. Antiangiogenic treatment with sunitinib ameliorates inflammatory infiltrate, fibrosis, and portal pressure in cirrhotic rats. Hepatology 2007;46(6):1919-1926. [PubMed: 17935226]

121. Caligiuri A, Bertolani C, Guerra CT, et al. Adenosine monophosphate-activated protein kinase modulates the activated phenotype of hepatic stellate cells. Hepatology 2008;47(2):668-676. [PubMed: 18098312]

122. Benedetti A, Di Sario A, Casini A, et al. Inhibition of the $\mathrm{NA}(+) / \mathrm{H}(+)$ exchanger reduces rat hepatic stellate cell activity and liver fibrosis: an in vitro and in vivo study. Gastroenterology 2001;120(2): 545-556. [PubMed: 11159895]

123. Demetri GD, von Mehren M, Blanke CD, et al. Efficacy and safety of imatinib mesylate in advanced gastrointestinal stromal tumors. N Engl J Med 2002;347(7):472-480. [PubMed: 12181401]

124. Druker BJ, Sawyers CL, Kantarjian H, et al. Activity of a specific inhibitor of the BCR-ABL tyrosine kinase in the blast crisis of chronic myeloid leukemia and acute lymphoblastic leukemia with the Philadelphia chromosome. N Engl J Med 2001;344(14):1038-1042. [PubMed: 11287973]

125. Yoshiji H, Noguchi R, Kuriyama S, et al. Imatinib mesylate (STI-571) attenuates liver fibrosis development in rats. Am J Physiol Gastrointest Liver Physiol 2005;288(5):G907-G913. [PubMed: 15618280]

126. Neef M, Ledermann M, Saegesser H, et al. Oral imatinib treatment reduces early fibrogenesis but does not prevent progression in the long term. J Hepatol 2006;44(1):167-175. [PubMed: 16168515]

127. Tada S, Iwamoto H, Nakamuta M, et al. A selective ROCK inhibitor, Y27632, prevents dimethylnitrosamine- induced hepatic fibrosis in rats. J Hepatol 2001;34(4):529-536. [PubMed: 11394652]

128. Borkham-Kamphorst E, Stoll D, Gressner AM, Weiskirchen R. Antisense strategy against PDGF B-chain proves effective in preventing experimental liver fibrogenesis. Biochem Biophys Res Commun 2004;321(2):413-423. [PubMed: 15358192]

129. Stefanovic B, Schnabl B, Brenner DA. Inhibition of collagen a1(I) expression by the 5' stem-loop as a molecular decoy. J Biol Chem 2002;11:11.

130. Lindquist JN, Parsons CJ, Stefanovic B, Brenner DA. Regulation of alpha1(I) collagen messenger RNA decay by interactions with alphaCP at the 3'-untranslated region. J Biol Chem 2004;279(22): 23822-23829. [PubMed: 14973140]

131. Stefanovic B, Stefanovic L, Schnabl B, Bataller R, Brenner DA. TRAM2 protein interacts with endoplasmic reticulum $\mathrm{Ca} 2+$ pump Serca2b and is necessary for collagen type I synthesis. Mol Cell Biol 2004;24(4):1758-1768. [PubMed: 14749390]

132. Stefanovic L, Stephens CE, Boykin D, Stefanovic B. Inhibitory effect of dicationic diphenylfurans on production of type I collagen by human fibroblasts and activated hepatic stellate cells. Life Sci 2005;76(17):2011-2026. [PubMed: 15707883]

133. Kershenobich D, Vargas F, Garcia-Tsao G, Perez Tamayo R, Gent M, Rojkind M. Colchicine in the treatment of cirrhosis of the liver. N Engl J Med 1988;318(26):1709-1713. [PubMed: 3287167]

134. Cortez-Pinto H, Alexandrino P, Camilo ME, et al. Lack of effect of colchicine in alcoholic cirrhosis: final results of a double blind randomized trial. Eur J Gastroenterol Hepatol 2002;14(4):377-381. [PubMed: 11943949]

135. George J, Roulot D, Koteliansky VE, Bissell DM. In vivo inhibition of rat stellate cell activation by soluble transforming growth factor beta type II receptor: a potential new therapy for hepatic fibrosis. Proc Natl Acad Sci U S A 1999;96(22):12719-12724. [PubMed: 10535989]

136. Friedman SL. Mechanisms of hepatic fibrosis and therapeutic implications. Nature Clinical Practice in Gastroenterology \& Hepatology 2004;1(2):98-105.

137. Okuno M, Akita K, Moriwaki H, et al. Prevention of rat hepatic fibrosis by the protease inhibitor, camostat mesilate, via reduced generation of active TGF-beta. Gastroenterology 2001;120(7): 1784-1800. [PubMed: 11375959]

138. Zheng S, Chen A. Disruption of transforming growth factor-beta signaling by curcumin induces gene expression of peroxisome proliferator-activated receptor-gamma in rat hepatic stellate cells. Am J Physiol Gastrointest Liver Physiol 2007;292(1):G113-G123. [PubMed: 16959952] 
139. Leclercq IA, Farrell GC, Sempoux C, dela Pena A, Horsmans Y. Curcumin inhibits NF-kappaB activation and reduces the severity of experimental steatohepatitis in mice. J Hepatol 2004;41(6): 926-934. [PubMed: 15582125]

140. Dooley D, Hamzavi J, Breitkopf K. Smad7 prevents activation of hepatic stellate cells and liver fibrosis in rats. Gastroenterology 2003;125:178-191. [PubMed: 12851882]

141. Masuda H, Fukumoto M, Hirayoshi K, Nagata K. Coexpression of the collagen-binding stress protein HSP47 gene and the alpha 1(I) and alpha 1(III) collagen genes in carbon tetrachloride induced rat liver fibrosis. J Clin Invest 1994;94(6):2481-2488. [PubMed: 7989606]

142. Nagata K. Expression and function of heat shock protein 47: a collagen-specific molecular chaperone in the endoplasmic reticulum. Matrix Biol 1998;16(7):379-386. [PubMed: 9524358]

143. Zhu J, Wu J, Frizell E, et al. Rapamycin inhibits hepatic stellate cell proliferation in vitro and limits fibrogenesis in an in vivo model of liver fibrosis. Gastroenterology 1999;117(5):1198-1204. [PubMed: 10535884]

144. Trotter JF. Sirolimus in liver transplantation. Transplant Proc 2003;35(3 Suppl):193S-200S. [PubMed: 12742496]

145. Williams EJ, Benyon RC, Trim N, et al. Relaxin inhibits effective collagen deposition by cultured hepatic stellate cells and decreases rat liver fibrosis in vivo. Gut 2001;49(4):577-583. [PubMed: 11559657]

146. Bennett RG, Mahan KJ, Gentry-Nielsen MJ, Tuma DJ. Relaxin receptor expression in hepatic stellate cells and in cirrhotic rat liver tissue. Ann N Y Acad Sci 2005;1041:185-189. [PubMed: 15956705]

147. Rockey DC, Chung JJ. Endothelin antagonism in experimental hepatic fibrosis. Implications for endothelin in the pathogenesis of wound healing. J Clin Invest 1996;98(6):1381-1388. [PubMed: 8823303]

148. Rockey DC. Antifibrotic therapy in chronic liver disease. Clin Gastroenterol Hepatol 2005;3(2):95107. [PubMed: 15704042]

149. Fiorucci S, Antonelli E, Morelli O. NCX-1000, a NO-releasing derivative of ursodeoxycholic acid, selectively delivers NO to the liver and protects against development of portal hypertension. PNAS 2001;98:8897-8902. [PubMed: 11447266]

150. Iredale JP, Benyon RC, Pickering J, et al. Mechanisms of spontaneous resolution of rat liver fibrosis. Hepatic stellate cell apoptosis and reduced hepatic expression of metalloproteinase inhibitors. J Clin Invest 1998;102(3):538-549. [PubMed: 9691091]

151. Parsons CJ, Bradford BU, Pan CQ, et al. Antifibrotic effects of a tissue inhibitor of metalloproteinase-1 antibody on established liver fibrosis in rats. Hepatology 2004;40(5):11061115. [PubMed: 15389776]

152. Roderfeld M, Weiskirchen R, Wagner S, et al. Inhibition of hepatic fibrogenesis by matrix metalloproteinase-9 mutants in mice. Faseb J 2006;20(3):444-454. [PubMed: 16507762]

153. Melhem A, Muhanna N, Bishara A, et al. Anti-fibrotic activity of NK cells in experimental liver injury through killing of activated HSC. J Hepatol 2006;45(1):60-71. [PubMed: 16515819]

154. Inagaki Y, Nemoto T, Kushida M, et al. Interferon alfa down-regulates collagen gene transcription and suppresses experimental hepatic fibrosis in mice. Hepatology 2003;38(4):890-899. [PubMed: 14512876]

155. Jeong WI, Park O, Gao B. Abrogation of the antifibrotic effects of natural killer cells/interferongamma contributes to alcohol acceleration of liver fibrosis. Gastroenterology 2008;134(1):248258. [PubMed: 18166357]

156. Dekel R, Zvibel I, Brill S, Brazovsky E, Halpern Z, Oren R. Gliotoxin ameliorates development of fibrosis and cirrhosis in a thioacetamide rat model. Dig Dis Sci 2003;48(8):1642-1647. [PubMed: 12924662]

157. Wright M, Issa R, Smart D. Gliotoxin stimulates the apoptosis of human and rat hepatic stellate cells and enhances the resolution of liver fibrosis in rats. Gastroenterology 2001;121:685-698. [PubMed: 11522753]

158. Oakley F, Meso M, Iredale JP, et al. Inhibition of inhibitor of kappaB kinases stimulates hepatic stellate cell apoptosis and accelerated recovery from rat liver fibrosis. Gastroenterology 2005;128 (1):108-120. [PubMed: 15633128] 
159. Iwamoto H, Sakai H, Kotoh K, Nakamuta M, Nawata H. Soluble Arg-Gly-Asp peptides reduce collagen accumulation in cultured rat hepatic stellate cells. Dig Dis Sci 1999;44(5):1038-1045. [PubMed: 10235616]

160. Taimr P, Higuchi H, Kocova E, Rippe RA, Friedman S, Gores GJ. Activated stellate cells express the TRAIL receptor-2/death receptor-5 and undergo TRAIL-mediated apoptosis. Hepatology 2003;37(1):87-95. [PubMed: 12500193]

161. Fallowfield JA, Iredale JP. Targeted treatments for cirrhosis. Expert Opin Ther Targets 2004;8(5): 423-435. [PubMed: 15469393]

162. Siller-Lopez F, Sandoval A, Salgado S, et al. Treatment with human metalloproteinase-8 gene delivery ameliorates experimental rat liver cirrhosis. Gastroenterology 2004;126(4):1122-1133. discussion 949. [PubMed: 15057751]

163. Iimuro Y, Nishio T, Morimoto T, et al. Delivery of matrix metalloproteinase-1 attenuates established liver fibrosis in the rat. Gastroenterology 2003;124(2):445-458. [PubMed: 12557150]

164. Issa R, Zhou X, Trim N, et al. Mutation in collagen-1 that confers resistance to the action of collagenase results in failure of recovery from CCl4-induced liver fibrosis, persistence of activated hepatic stellate cells, and diminished hepatocyte regeneration. Faseb J 2003;17(1):47-49. [PubMed: 12475903] 


\section{Perpetuation}

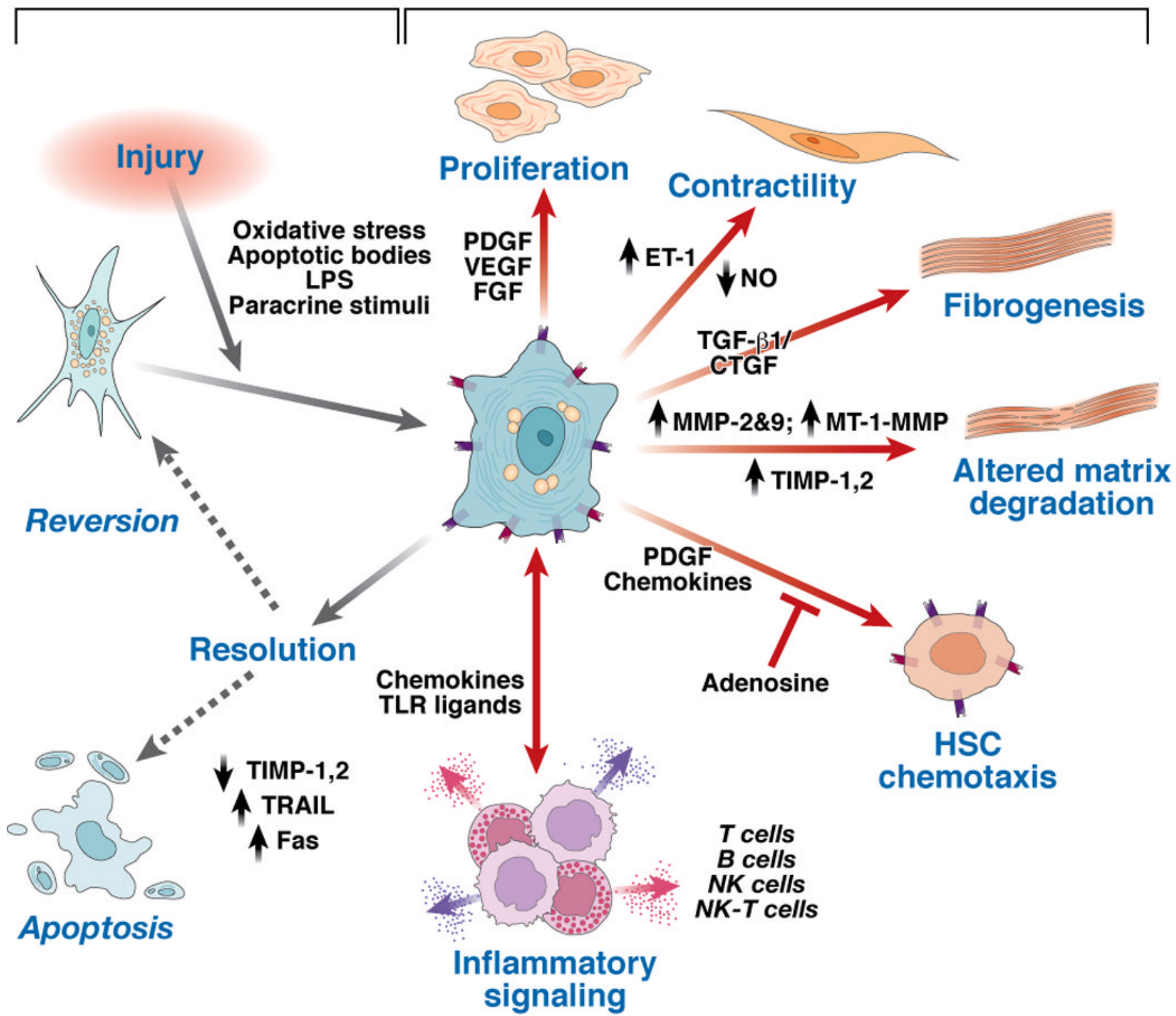

Figure 1. Pathways of stellate cell activation and fibrogenesis

Pathways of hepatic stellate cell activation. Features of stellate cell activation can be distinguished between those that stimulate initiation, and those that contribute to perpetuation. Initiation is provoked by soluble stimuli that include oxidant stress signals (reactive oxygen intermediates), apoptotic bodies, lipopolysaccharide (LPS) and paracrine stimuli from neighboring cell types including hepatic macrophages (Kupffer cells), sinusoidal endothelium and hepatocytes. Perpetuation follows, characterized by a number of specific phenotypic changes including proliferation, contractility, fibrogenesis, altered matrix degradation, chemotaxis, and inflammatory signaling. (Abbreviations: PDGF - platelet derived growth factor, VEGF - vascular endothelial growth factor; FGF- fibroblast growth factor; ET-1 endothelin-1; NO - nitric oxide; TGF $\beta 1$ - transforming growth factor beta 1; CTGF connective tissue growth factor; MMP- matrix metalloproteinase; MT-MMP - membrane type 
matrix metalloproteinase; TIMP - tissue inhibitor of metalloproteinase; TLR- toll like receptor). Reprinted from $\operatorname{Ref}^{1}$, with permission. 
TABLE 10.2

Therapeutic Strategies For Hepatic Fibrosis

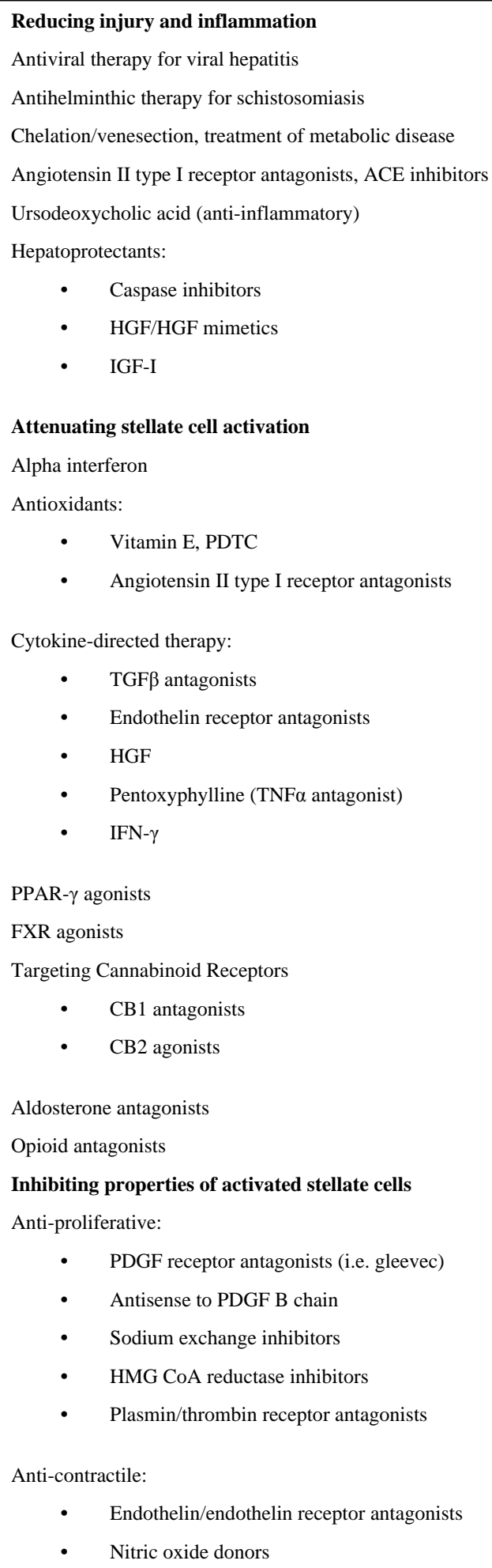

- Endothelin/endothelin receptor antagonists

- $\quad$ Nitric oxide donors 
- Inhibition of Rho-mediated focal adhesions

Anti-fibrogenic:

- Collagen synthesis inhibitors

- $\quad$ Collagen folding inhibition (siRNA to Hsp47)

- $\quad$ TGF $\beta$ inhibitors (soluble receptors, neutralizing antibodies)

- HGF/HGF mimetics

- $\quad$ AT receptor antagonists

- ACE inhibitors

- Integrin

- $\mathrm{CTGF} / \mathrm{CCN}$ antagonists

- $\quad$ SMAD 7 agonists

- Relaxin

Promoting specific apoptosis of hepatic stellate cells

Gliotoxin

NGF agonists

TIMP antagonists

TRAIL ligands

Degrading scar matrix

Direct collagenase administration

Inhibitors of transglumatinase or collagen crosslinking

TIMP antagonists

TGF- $\beta$ inhibitors

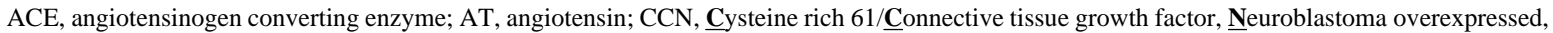
FXR, farnesyl X receptor; HGF, hepatocyte growth factor; HMG CoA, 3-Hydroxy-3-Methyl-Glutaryl Coenzyme A; NGF, nerve growth factor; NOV, nephroblastoma overexpressed; PDGF, platelet derived growth factor; PDTC, pyrrolidine dithiocarbamate; PPAR, peroxisome proliferators activated receptor; SMAD; mothers against DPP homolog 7; TIMP, tissue inhibitor of metalloproteinase; TGF- $\beta$, transforming growth factor beta. 